\title{
Laboratory Findings Suggesting an Association Between BoHV-4 and Bovine Abortions in Southern Belgium
}

\author{
L. Delooz ${ }^{1,2}$, G. Czaplicki ${ }^{1}$, J. Y. Houtain ${ }^{1}$, F. Dal Pozzo ${ }^{2}$ and C. Saegerman ${ }^{2}$ \\ 1 Département Santé Animale, Association Régionale de Santé et d'Identification Animales - ASBL, Ciney, Belgium \\ 2 Research Unit of Epidemiology and Risk Analysis applied to Veterinary Sciences (UREAR-ULg), Centre for Fundamental and Applied Research for \\ Animals \& Health (FARAH), Faculty of Veterinary Medicine, University of Liege, Liege, Belgium
}

\section{Keywords:}

abortion; cattle; bovine herpesvirus 4 (BoHV4); epidemiology; pathogenesis; Belgium

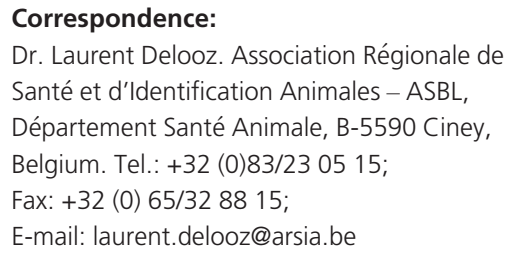

doi:10.1111/tbed.12469

\begin{abstract}
Summary
Abortions cause heavy economic losses for the bovine sector. The use of a standardized panel of analyses covering a large spectrum of pathogens responsible of abortion in cattle allowed demonstrating the direct involvement of at least one pathogen in $57 \%$ of analysed abortions in the southern part of Belgium. This result suggests a margin of improvement in the diagnostic efficacy. In order to evaluate the interest to broaden the list of pathogens included in the panel of analyses, the implication of bovine herpesvirus 4 (BoHV-4) in abortion was assessed by two different studies. In the first study, coupled serology was performed after abortion on 714 dams to identify specific seroconversion against BoHV-4. The overall seroconversion in cows was $19.5 \%$, with a higher frequency in primiparous compared to multiparous females. In addition, the type of breed (beef cattle) and the time period from the fourth quarter 2008 until the last quarter 2009 were significantly related to the seroconversion of cows. The second study investigated the virus ability to infect the foetus. In this study, 368 cases of bovine abortions were specifically tested for BoHV-4, using PCR on foetus tissues and ELISA on dam and foetus sera. The results showed a maternal seroprevalence of $64.7 \%$, a foetal seroprevalence of $0.8 \%$ and a PCR prevalence in foetuses of $1.1 \%$, demonstrating the ability of BoHV-4 to infect the foetus.
\end{abstract}

\section{Introduction}

Belgium was recognized officially free from bovine brucellosis in 2003. Consequently, the national surveillance programme has been based on the compulsory reporting of abortions and subsequent analyses on their products. In this context, the Regional Association of Animal Health and Identification (ARSIA), under the supervision of the Federal Agency for the Safety of the Food Chain (FASFC), proposed a large standardized panel of analyses (Table 1). The panel was designed to extend the diagnosis of bovine abortions on submitted foetuses to other diseases than brucellosis. The aim was to increase the number of abortion declarations by providing the animal's owner and veterinarian an aetiological diagnosis of the abortion. However, determining the cause of bovine abortions is a laborious task, involving methods for direct and/or indirect detection of pathogens such as bacteria (Brucella spp., Campylobacter spp., Coxiella burnetii, Leptospira hardjo, Listeria monocytogenes, Neospora caninum, Salmonella dublin), viruses (bluetongue virus serotype 8 (BTV-8), bovine herpesvirus 1 (BoHV-1), bovine viral diarrhoea virus (BVDV)), several mycotic agents and many other opportunistic bacteria. Despite this wide range of analyses, the cause of abortion could not be determined for a significant number of cases. Therefore, the option to expand the panel of laboratory analyses to other potential pathogens of abortion was evaluated.

In the past, the presence of bovine herpesvirus 4 (BoHV4) in Belgium was recorded (Wellemans, 1984; Van Malderen et al., 1987; Wellemans and Van Opdenbosch, 1989), as well as an association between BoHV-4 seropositivity and 
Table 1. List of pathogens included and diagnostic method applied in the standardized panel of analyses

\begin{tabular}{|c|c|c|c|c|}
\hline \multirow[b]{2}{*}{ Pathogens } & \multicolumn{2}{|l|}{ Foetus } & \multirow{2}{*}{$\begin{array}{l}\text { Foetal serum } \\
\text { Methods }\end{array}$} & \multirow{2}{*}{$\begin{array}{l}\text { Maternal serum } \\
\text { Methods }\end{array}$} \\
\hline & Samples & Methods & & \\
\hline Brucella spp. & Abomasal fluid & Culture & & SAW/ELISA Ab \\
\hline Campylobacter foetus spp. & Abomasal fluid & Culture & & \\
\hline Coxiella burnetii & Abomasal fluid & $P C R^{c}$ & & ELISA Ab \\
\hline Listeria monocytogenes & Abomasal fluid & Culture & & \\
\hline Mycotic agents & Abomasal fluid & Culture & & \\
\hline Opportunistic bacteria & Abomasal fluid & Culture $^{a}$ & & \\
\hline Salmonella spp. & Abomasal fluid & Culture & & \\
\hline BTV-8 & Brain & PCR & & \\
\hline Neospora caninum & Brain & $\mathrm{PCR}$ & & ELISA Ab \\
\hline Schmallenberg virus & Brain & $P C R^{c}$ & & \\
\hline BoHV-4 & Spleen & $P C R^{C}$ & ELISA $A b^{c}$ & ELISA Ab \\
\hline BVDV & Spleen & ELISA Ag & & ELISA Ab \\
\hline Leptospira spp. & Kidney & $P C R^{C}$ & ELISA $A b^{c}$ & ELISA Ab \\
\hline BoHV-1 & Trachea & $P C R^{b}$ & & ELISA Ab \\
\hline
\end{tabular}

PCR, polymerase chain reaction; Ab, antibody; Ag, antigen; SAW, sero-agglutination of Wright.

anly the presence of a pure culture on blood agar is indicative of opportunistic bacteria.

${ }^{\mathrm{b}}$ Applied during the first study.

${ }^{C}$ Applied during the second study; BVDV, bovine viral diarrhoea virus; BTV-8, bluetongue virus serotype 8; BoHV-1, bovine herpesvirus 1; BoHV-4, bovine herpesvirus 4 .

abortion in cows (Czaplicki and Thiry, 1998; Treilles et al., 2013). Wellemans and Van Opdenbosch (1989) showed that during abortions $14.1 \%$ cows seroconverted against BoHV-4 in Belgium. Furthermore, direct detection of this virus in bovine abortions has been successfully investigated in several studies (Reed et al., 1979; Wellemans and Van Opdenbosch, 1989). In the state of Dakota (USA), BoHV-4 was isolated from $0.52 \%$ aborted foetuses (Kirkbride, 1992). In Hungary, Deim et al. (2007) demonstrated the presence of BoHV-4 DNA by PCR in the spleen of 7 foetuses (29\%) and in $18.18 \%$ placentas from 24 aborted cows (Deim et al., 2006). Foetal serological diagnosis was also made from thoracic fluid (Naeem et al., 1989) where specific antibodies against BoHV-4 were detected in 1.2\% aborted foetuses. Furthermore, Deim et al. (2006) could detect BoHV-4 DNA from samples of bovine abortions and successfully localize the virus by in situ hybridization into damaged placental epithelial cells. The intravenous inoculation of BoHV-4 strain LVR140 to pregnant cows caused metritis, approximately one week after parturition (Wellemans et al., 1986; Wellemans and Van Opdenbosch, 1987). In 1976, a strain of BoHV-4, isolated from a case of metritis, was inoculated to cows at different periods of gestation (Kendrick et al., 1976) and two foetuses died in the first half of gestation.

In the absence of an aetiological diagnosis of all bovine abortions in the south part of Belgium, the objectives of this work were (i) to determine the proportion of abortions associated with the BoHV-4 infection, compared to the main causes of bovine abortions and (ii) to verify the ability of the virus to infect foetuses under field conditions. Furthermore, risk factors such as breed, number of parity and month of pregnancy associated with the BoHV-4 exposure in aborted cows that seroconverted, were investigated.

\section{Materials and Methods}

Studies and study area

Two studies were conducted in the southern part of Belgium, including five different provinces (Walloon Brabant, Hainaut, Namur, Liege and Luxembourg). In the study area, 12000 cattle herds with 1257000 bovines are registered.

In the first study, coupled serology was performed after abortion on 714 dams to identify specific seroconversion against BoHV-4. In the second study, the virus ability to infect the foetus was investigated and 368 cases of bovine abortions were specifically tested for BoHV-4, with PCR on foetus tissues and ELISA on dam and foetus sera.

\section{Sampling design}

Samples were obtained in the context of the passive surveillance programme for brucellosis and collected by the local veterinary practitioner within $48 \mathrm{~h}$ after abortion. Samples were sent, together with an anamnesis, to the regional laboratory (Regional Association of Animal Health and Identification, ARSIA).

Between October 2007 and October 2009, a total of 1165 cases of bovine abortions were submitted to the laboratory 
(Fig. 1a). Sera were tested using the standardized panel of analyses (Table 1) and were subsequently stored at $-20^{\circ} \mathrm{C}$.

In the first study, 714 bovine abortions (61.29\% of the total cases) were further characterized by analyses performed on coupled serum collected by the veterinary practitioner with an average interval of 32 days after the first date of sampling. Of these 714 cases, 705 included a foetus on which both an autopsy and a panel of analyses were performed. In addition, the seroprevalence at the time of abortion was also estimated.

In the second study, only the bovine abortions submitted to the laboratory from January 4 to February 72012 together with at least the maternal serum and the aborted foetus were included. Indeed, a total of 593 cases were submitted to the laboratory of which 368 were randomly selected for future analyses (Fig. 1b).
In the necropsy room, blood was sampled on Whatman $3 \mathrm{MM}$ CHRO blotting paper in the heart or the femoral vein of foetus. Briefly, blood spots were dried for $6 \mathrm{~h}$ before storage at room temperature until analysis. For analysis, a disc is cut with a card punch to obtain a 6-mm-diameter blood impregnated disc. A disc saturated with blood yields an eluate of $250 \mu \mathrm{l}$ corresponding to a $1 / 25$ dilution of serum (Bailey et al., 1967).

The information issued from the anamnesis, such as the sampling date, the herd identification number, the cattle breed, the month of pregnancy and the number of parity, was recorded in the laboratory information management system or in an Access ${ }^{\circledR}$ database. The geographical localization of each case of abortion was possible using the Lambert coordinates and the Belgian cattle identification and movement traceability system (SANITRACE).

(a)

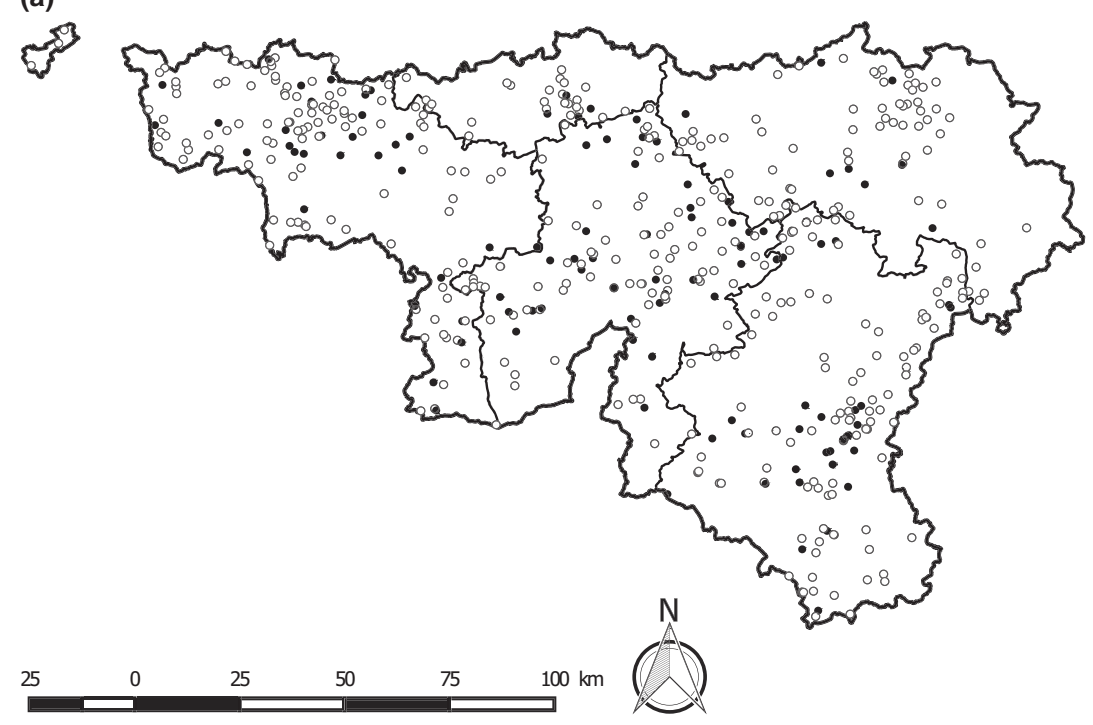

(b)

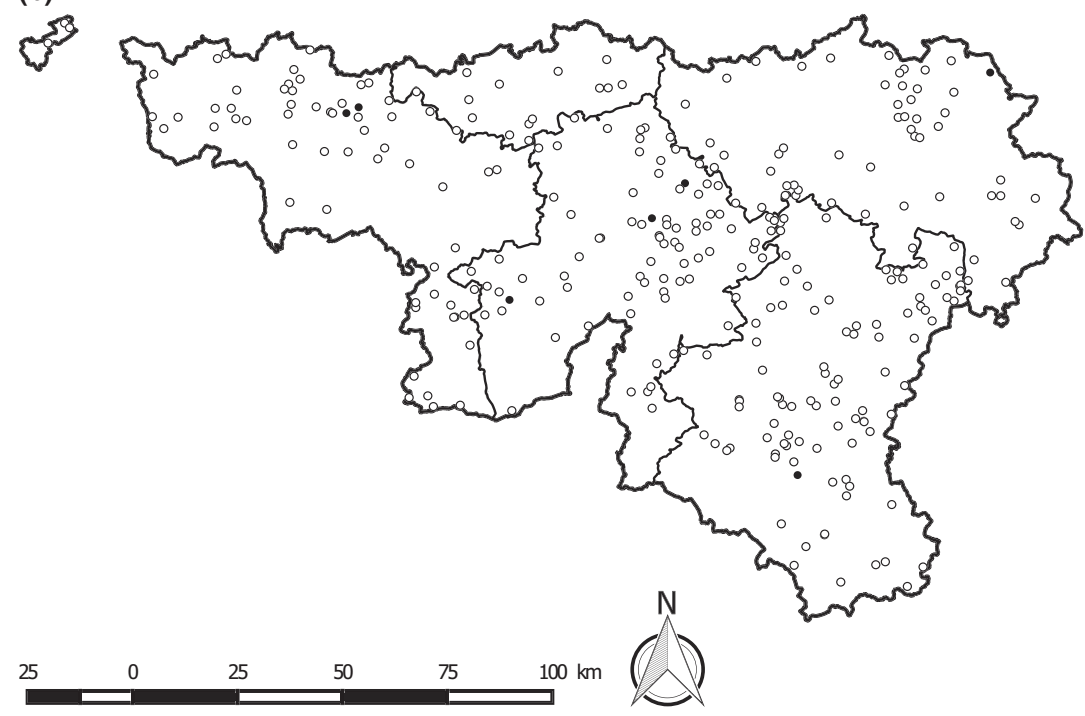

Fig. 1. Location of the bovine abortion cases included in the first (a) $(n=714)$, and the second (b) $(n=368)$ study performed in the southern part of Belgium. (a) White dots correspond to cases without seroconversion, and black dots correspond to cases with seroconversion; (b) white dots correspond to noninfected foetuses (ELISA or PCR negative), and black dots correspond to infected foetuses (ELISA or PCR positive). 


\section{Laboratory analyses}

\section{Standardized panel of analyses}

In the laboratory, depending on the availability and quality of material, all analyses specified in the standardized panel were made (Table 1).

\section{Serological diagnosis of $\mathrm{BoHV}-4$}

The diagnosis of BoHV-4 in the maternal serum was performed using an indirect ELISA test (Edwards and Newman, 1985; Wellenberg et al., 1999) according to the manufacturer's instructions (BIO K 263/2 ${ }^{\circledR}$, BioX Diagnostics, Rochefort, Belgium). Concerning the foetal serology, the same ELISA was performed using a $6 \mathrm{~mm}$ disc of saturated blood (Bailey et al., 1967). The optical densities of the positive and negative sera (OD pos and OD neg) and those of all the samples (OD samples) were measured. The following ratio $\mathrm{S} / \mathrm{P}$ (sample/positive control) expressed in per cent was calculated:

$$
\begin{aligned}
\text { Ratio } \mathrm{S} / \mathrm{P}= & {[(\mathrm{OD} \text { sample }-\mathrm{OD} \text { neg }) /(\mathrm{OD} \text { pos }} \\
& -\mathrm{OD} \text { neg })] * 100
\end{aligned}
$$

The interpretation of the results was carried out according to the following magnitude scale: negative (ratio $\leq 30 \%$ ), + (ratio $>30 \%$ and $\leq 60 \%$ ), ++ (ratio $>60 \%$ and $\leq 90 \%$ ), $+++($ ratio $>90 \%$ and $\leq 120 \%$ ), ++++ (ratio $>120 \%$ and $\leq 150 \%$ ), +++++ (ratio $>150 \%$ ).

The implication of BoHV-4 was only suspected if a seroconversion could be observed using two coupled serum samples taken with a minimum interval of 2 weeks. In this study, a seroconversion against BoHV-4 was considered to have occurred if the signal increases by at least two orders of magnitude (for example, - to ++ or + to +++ ). A primary BoHV-4 infection was considered if a cow was seronegative at time of abortion and become seropositive at the second bleeding with at least two orders of magnitude $(\geq++)$.

\section{Direct detection of $\mathrm{BoHV}-4$}

Direct diagnosis of BoHV-4 was performed on spleen fragments stored at $-20^{\circ} \mathrm{C}$. DNA extraction was performed using KingFisher ${ }^{\mathrm{TM}}$ Flex 96 Magnetic Particle Processors (Thermo Scientific ${ }^{\mathrm{TM}}$, UK) and LSI MagVet ${ }^{\mathrm{TM}}$ Universal Isolation Kit (Life Technologies, UK) and was followed by BoHV-4 DNA detection using a commercial PCR test (LSI VetMax BoHV $-4^{\circledR}$ TM, Life Technologies, $\mathrm{UK}$ ), according to the manufacturer's instructions (Wellenberg et al., 2001). The PCR reactions were performed with a Stratagene Mx3500P (Agilent Technologies, USA). According to the manufacturer's instructions, a sample was considered positive for a threshold cycle $(=\mathrm{Ct})$ value lower than 46.

\section{Statistical analysis}

The representativeness of the abortion cases included in both studies was verified indirectly with respect to the location (province) and the sampling date, using the Pearson correlation coefficient. Measurement of the relationship between two variables was taken by calculating the Pearson correlation coefficient $(r)$ as parametric test or a Spearman rank correlation $\left(r_{s}\right)$ as nonparametric test (Dean et al., 1990). The confidence interval (95\% CI) of prevalence was estimated using an exact binomial distribution. The increase of BoHV-4 prevalence in time was assessed using a chi-square test for linear trend. In the first study, a univariate analysis and secondly a multivariate logistic regression using backward stepwise analysis were used to check the relation between the BoHV-4 seroconversion of aborted dams and explanatory variables (Petrie and Watson, 2006; StataCorp, 2012). The following explanatory variables and their respective reference classes were used as follows province of origin of the dam (Walloon Brabant as reference), time of occurrence of abortion (quarter 4 of 2007 as reference), number of parity (first parity as reference) and month of pregnancy (month 3 as reference). The breed (beef or dairy cattle), the aetiological diagnosis (presence or absence) and the opportunistic bacteria (presence or absence) were others explanatory binary variables. In addition, to assess the collinearity, a backward elimination of variables was performed (Preux et al., 2005). If a variable induced a modification of the odds ratio of more than $20 \%$, this variable was retained in the final model where the interaction was tested in case of biological relevance. Goodness of fit was assessed using the Hosmer-Lemeshow goodness-of-fit test. Statistical analyses were performed using STATA/SE Acad. 12 (Stata Corp., College Station, Texas).

\section{Results}

Study 1: BoHV-4 serology associated with bovine abortion During the study period going from October 2007 and October 2009, the Pearson correlation test indirectly confirmed that the samples were randomly selected among all cases of abortions. The random selection was verified considering the time period during which the abortion occurred (expressed in quarters during the study period) $(r=0.98, P$-value $<0.0001)$ and the geographic origin (expressed in provinces $)(r=0.97, P$-value $=0.006)$.

\section{Seroprevalence at the time of abortion}

In total, 760 cows of 1,158 (65.6\%; 95\% CI: 62.8-68.4\%) were seropositive at first sampling ( 7 results were not interpretable) and the apparent seroprevalence remained stable during the period from the last quarter of 2007 until the third quarter of 2008. The apparent seroprevalence increased significantly and continuously from the fourth 
quarter 2008 until the last quarter 2009 (chi-square for linear trend $=24.4 ; 7 \mathrm{df} ; P$-value $=0.001)$. In addition, no significant difference in apparent seroprevalence was observed between types of breed (dairy versus beef) $\left(\chi^{2}=0.99 ; 1 \mathrm{df} ; P\right.$-value $\left.=0.32\right)$.

The seropositivity increased with parity number, going from $50.2 \%$ in primiparous to $76.1 \%$ in females with $\geq 4$ pregnancies (Table 2). A linear relationship between the seropositivity and the parity number was noted $(r=0.96$, $P<0.04)$.

\section{Seroconversion}

During the first study, 714 cows were sampled a second time after abortion for a coupled BoHV-4 serology. Based on an increase of at least two orders of magnitude of the S/ $P$ ratio between the first and the second sampling, 113 cows were seropositive at the coupled serology against BoHV-4, among the 456 cattle that were seropositive only at first sampling. Of 258 seronegative cows at the time of abortion, 26 seroconverted at the second sampling, suggesting a correlation with BoHV-4 primary infection (Table 3).

\section{Associated risk factors}

\section{Univariate analysis}

The breed of the cow was available for $713(99.8 \%)$ analysed samples and 117 of 551 beef cows (21.2\%; 95 CI: 17.9$24.9 \%)$ seroconverted against BoHV-4 versus only 21 of 162 dairy cows (13.0\%; 95\% CI: 8.2-19.1). Dairy cows were significantly less likely to be seropositive (OR $=0.55 ; 95 \%$ CI: 0.33-0.90).

The parity of the cow was available for 693 (97.1\%) analysed samples, and no significant difference in seroconversion between the number of parity was noted. However, the percentage of primary infection decreased with the number of parity (Pearson's correlation coefficient $=0.98$, $P$-value $=0.0001)$. This percentage was $4.43 \%$ in the primiparous group and decreased to $1.71 \%$ in the multiparous group with parity equal or $>4$.

The month of gestation at the time of abortion was available for $700(98.0 \%)$ samples. The seroconversion percent-
Table 3. Results of coupled serology against BoHV-4 in dams after abortion ( $n=714$ cows)

\begin{tabular}{|c|c|c|c|c|c|c|c|}
\hline & \multicolumn{6}{|c|}{ First serology } & \multirow[b]{2}{*}{ Total } \\
\hline & - & + & ++ & +++ & ++++ & +++++ & \\
\hline \multicolumn{8}{|c|}{ Second serology } \\
\hline- & 201 & 21 & 3 & 0 & 1 & 0 & 226 \\
\hline+ & 31 & 35 & 10 & 2 & 0 & 0 & 78 \\
\hline++ & 12 & 33 & 43 & 6 & 3 & 1 & 98 \\
\hline+++ & 7 & 23 & 42 & 40 & 5 & 0 & 117 \\
\hline++++ & 7 & 22 & 38 & 45 & 21 & 5 & 138 \\
\hline+++++ & 0 & 4 & 7 & 19 & 10 & 17 & 57 \\
\hline Total & 258 & 138 & 143 & 112 & 40 & 23 & 714 \\
\hline
\end{tabular}

Cows with seroconversion are highlighted in grey. A seroconversion against BoHV-4 was considered to occur if the S/P ratio increased by two orders of magnitude (for example, - to ++ , or + to +++ ).

age increased from $0 \%$, for abortions occurring at 3 months, to $36.0 \%$ for abortions occurring at 9 months of gestation (Fig. 2). A nonparametric relationship between the month of gestation at abortion and the seroconversion percentage was observed $\left(r_{s}=1, P\right.$-value $\left.<0.0001\right)$.

Among the 714 cases of abortion with a coupled serology, the foetus could be included in the study in 705 (98.7\%) cases and at least one pathogen was identified, using the standardized panel of analyses, in 51.6\% abortions (Table 4). Based on these results, when a seroconversion against BoHV-4 was observed in the dam, the probability of isolating an opportunistic bacteria was significantly more important (OR: 5.29, 95\% CI: 2.27-12.30; $P$-value $<0.001)$. However, no such association could be observed with primo-infected cows or seropositive cows at first sampling. The most commonly isolated opportunistic bacteria were, in order of importance, Trueperella pyogenes, E. coli, Serratia marcescens and Bacillus spp.

\section{Multivariate analysis}

In addition, a multivariate analysis was performed on 700 (98\%) cases of abortions including coupled serum. The explicative variables were province of origin of the dam, time of the year when abortion occurred (expressed in

Table 2. Seropositivity (expressed in percentage) against BoHV-4 measured in dams after abortion depending on the number of parity $(n=714)$

\begin{tabular}{|c|c|c|c|c|c|c|c|c|}
\hline \multirow[b]{2}{*}{ Parity } & \multicolumn{6}{|c|}{ First serology } & \multirow[b]{2}{*}{ Total } & \multirow[b]{2}{*}{ Seropositivity (\%) } \\
\hline & - & + & ++ & +++ & ++++ & +++++ & & \\
\hline 1 & 101 & 38 & 25 & 24 & 10 & 5 & 203 & $50.2 \%$ \\
\hline 2 & 84 & 42 & 49 & 38 & 11 & 9 & 233 & $63.9 \%$ \\
\hline 3 & 38 & 30 & 29 & 28 & 10 & 5 & 140 & $72.9 \%$ \\
\hline$\geq 4$ & 28 & 27 & 35 & 17 & 6 & 4 & 117 & $76.1 \%$ \\
\hline N.D. & 7 & 1 & 5 & 5 & 3 & & 21 & $66.7 \%$ \\
\hline Total & 258 & 138 & 143 & 112 & 40 & 23 & 714 & \\
\hline
\end{tabular}


Fig. 2. Evolution of the seropositivity (left $Y$ axis) and the seroconversion percentages (right $Y$-axis) depending on the month of gestation (X-axis).

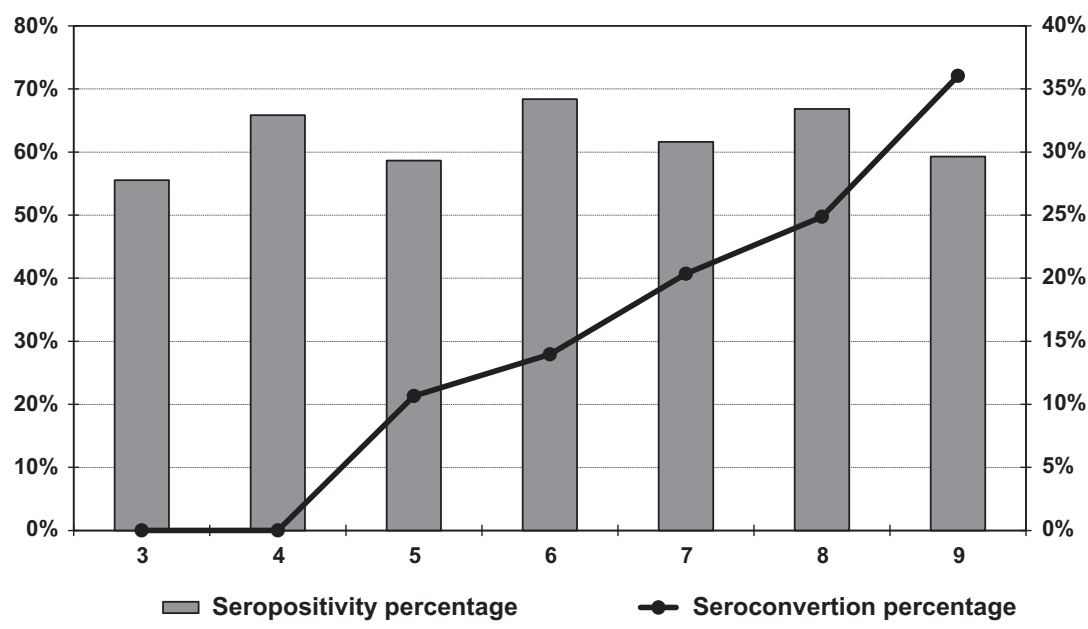

ables was not tested because of the lack of biological relevance. The Hosmer-Lemeshow test showed that the final model fit the data well $\left(\chi^{2}=0.82, \mathrm{df}=5, P\right.$-value $\left.=0.99\right)$.

\section{Study 2: BoHV-4's ability to infect the foetus}

The representativeness of included abortion cases was verified indirectly using Pearson's correlation coefficient $(r)$. The sample analysed at the beginning of 2012 was representative of all cases of abortions considering the time period

(Table 5$)$. The interaction between the two retained vari-

Table 4. Pathogens identified in the aborted foetuses (using a standardized panel of analyses), depending on the seroconversion of the dams against BoHV-4 (October 2007 to October 2009) $(n=705)$

\begin{tabular}{|c|c|c|c|c|c|c|c|}
\hline \multirow[b]{3}{*}{ Pathogens } & \multicolumn{3}{|c|}{$\begin{array}{l}\text { Seroconversion of dams against } \\
\text { BoHV-4 }\end{array}$} & \multicolumn{3}{|c|}{$\begin{array}{l}\text { No seroconversion of dams against } \\
\text { BoHV-4 }\end{array}$} & \multirow[b]{3}{*}{ Total } \\
\hline & \multicolumn{3}{|c|}{ Aborted foetus } & \multicolumn{3}{|c|}{ Aborted foetus } & \\
\hline & Neg. & Pos. & Subtotal & Neg. & Pos. & Subtotal & \\
\hline Opportunistic bacteria & 7 & 50 & 57 & 77 & 104 & 181 & 238 \\
\hline BVDV & 0 & 2 & 2 & 5 & 5 & 10 & 12 \\
\hline BVDV and opportunistic bacteria & 1 & 1 & 2 & 3 & 1 & 4 & 6 \\
\hline Listeria monocytogenes & 2 & 2 & 4 & 2 & 4 & 6 & 10 \\
\hline Listeria monocytogenes and BVDV & 0 & 0 & 0 & 1 & 0 & 1 & 1 \\
\hline Mycotic agents & 0 & 3 & 3 & 10 & 16 & 26 & 29 \\
\hline Mycotic agents and opportunistic bacteria & 0 & 0 & 0 & 1 & 3 & 4 & 4 \\
\hline Neospora caninum & 0 & 3 & 3 & 13 & 24 & 37 & 40 \\
\hline Neospora caninum and BTV-8 & 0 & 0 & 0 & 1 & 0 & 1 & 1 \\
\hline Neospora caninum and BVDV & 0 & 0 & 0 & 1 & 0 & 1 & 1 \\
\hline Neospora caninum and opportunistic bacteria & 0 & 1 & 1 & 6 & 5 & 11 & 12 \\
\hline Salmonella Dublin & 1 & 1 & 2 & 2 & 5 & 7 & 9 \\
\hline Yersinia pseudotuberculosis & 0 & 0 & 0 & 0 & 1 & 1 & 1 \\
\hline No identified pathogens & 14 & 50 & 64 & 108 & 169 & 277 & 341 \\
\hline At least one pathogen identified & 11 & 63 & 74 & 122 & 168 & 290 & 364 \\
\hline Total & 25 & 113 & 138 & 230 & 337 & 567 & 705 \\
\hline
\end{tabular}

Pos. and Neg., positive and negative status of the foetus regarding pathogen identification; BVDV, bovine viral diarrhoea virus; BTV-8, bluetongue virus serotype 8 . 
during which the abortion occurred (expressed in quarters during the study period $)(r=0.97, P$-value $=0.006)$ and the geographic origin (expressed in provinces) $(r=0.96, P$ value $=0.01$.

All pathogens included in the panel of analyses (Table 1) were investigated, and the results of the different tests are presented in the Table 6 . The degree of conservation of all foetuses included in the study $(n=368)$ was sufficient, and at least one pathogen, potentially responsible for the abortion, was identified in 209 (56.8\%) cases.

During this second study, antibodies against BoHV-4 were identified in sera of 279 cows of 368 cows collected after abortion (75.8\%; 95\% CI: 71.1-80.1\%). The DNA of BoHV-4 was detected by PCR in the spleen of four foetuses $(1.1 \%)$, and for three of them, no other specific pathogens or opportunistic bacteria could be identified (Table 7). These four foetuses aged between 6 and 9 months and came from seropositive cows at the time of abortion. However, these four foetuses were all seronegative regarding to BoHV-4. On the contrary, in the foetus where the highest Ct value for BoHV-4 could be measured in the spleen, an opportunistic bacterium (Trueperella pyogenes) was isolated from the abomasal fluid. The four PCR-positive samples presented a Ct value varying from 23 to 36. Three BoHV-4 seropositive but PCR-negative foetuses (0.8\%) were detected and were derived from seropositive cows. Opportunistic bacteria were isolated on the abomasal fluid of one of these three cases (E. coli).

The parity of the dams having had abortion was available for 299 of the 368 samples. Seropositivity by age group varied from $57.6 \%$ in primiparous to $95.0 \%$ in multiparous female with more than $\geq 4$ pregnancies. A linear relationship existed between the number of parity and seropositivity $(r=0.95 ; P$-value $=0.05)$.

Table 5. Risk factors associated with BoHV-4 seroconversion in dams after abortion using a multivariate logistic regression

\begin{tabular}{llll}
\hline Variable & & OR $(95 \% \mathrm{Cl})^{\mathrm{a}}$ & P-value \\
\hline Time of & Quarter 4 of 2007 & Reference & - \\
occurrence & Quarter 1 of 2008 & $1.06(0.60-1.88)$ & 0.84 \\
of abortion & Quarter 2 of 2008 & $2.62(1.28-5.39)$ & $0.009 *$ \\
(quarter) & Quarter 3 of 2008 & $1.82(0.85-3.94)$ & 0.13 \\
& Quarter 4 of 2008 & $1.28(0.68-2.41)$ & 0.44 \\
& Quarter 1 of 2009 & $0.46(0.23-0.92)$ & $0.03^{*}$ \\
& Quarter 2 of 2009 & $0.73(0.26-2.07)$ & 0.56 \\
& Quarters 3 and & $0.42(0.12-1.51)$ & 0.19 \\
Type of & 4 of 2009 & Reference & - \\
breed & Beef & & $0.003^{*}$ \\
& & $0.45(0.27-0.77)$ & 0.00 \\
\hline
\end{tabular}

${ }^{\mathrm{a} O R}$ : odds ratio and $\mathrm{Cl}$ : confidence interval

$* P$-value $<0.05$.

\section{Discussion}

The results of the first study confirmed that BoHV-4 infection was enzootic in the southern part of Belgium between 2007 and 2009 as already previously demonstrated (Van Malderen et al., 1987; Van Opdenbosch et al., 1986; Wellemans and Van Opdenbosch, 1989; Fitton et al., 1990; Cza-

Table 6. Pathogens in aborted foetuses identified using the standardized panel of analyses (see Table 1) from January 4 to 7 February 2012 ( $n=368$ foetuses)

\begin{tabular}{lcc}
\hline Pathogens & $n$. Foetuses & \% Foetuses \\
\hline Opportunistic bacteria & 130 & 35.3 \\
Neospora caninum & 20 & 5.4 \\
Mycotic agents & 13 & 3.5 \\
BVDV & 13 & 3.5 \\
Listeria monocytogenes & 11 & 3.0 \\
Salmonella Dublin & 4 & 1.1 \\
Neospora caninum/Opportunistic bacteria & 3 & 0.8 \\
BoHV-4 & 3 & 0.8 \\
Leptospira spp. & 2 & 0.5 \\
Ab BoHV-4 & 2 & 0.5 \\
Ab BoHV-4/Opportunistic bacteria & 1 & 0.3 \\
BoHV-4/Opportunistic bacteria & 1 & 0.3 \\
BVDV/Listeria monocytogenes & 1 & 0.3 \\
BVDV/Opportunistic bacteria & 1 & 0.3 \\
Campylobacter foetus spp. & 1 & 0.3 \\
Coxiella burnetii/Leptospira spp. & 1 & 0.3 \\
Neospora caninum/Opportunistic & 1 & 0.3 \\
bacteria/BVDV & & \\
Yersinia pseudotuberculosis & 1 & 0.3 \\
At least one pathogen identified & 209 & 56.8 \\
No identified pathogen & 159 & 43.2 \\
TOTAL & 368 & \\
\hline BVDV hovin Vira & &
\end{tabular}

BVDV, bovine viral diarrhoea virus; BoHV-4, bovine herpesvirus-4; Ab, antibody.

Table 7. Results of the specific BoHV-4 analysis in abortions $(n=368)$

\begin{tabular}{lllc}
\hline Maternal serology & Foetal serology & Foetal PCR (Ct value) & Number \\
\hline- & - & - & 89 \\
+ & - & - & 56 \\
+ & ++ & - & 1 \\
+ & - & $+(23)$ & 1 \\
++ & - & - & 85 \\
++ & - & 1 \\
++ & - & $-(31-34)$ & 2 \\
+++ & - & - & 62 \\
++++ & - & - & 41 \\
+++++ & - & - & 28 \\
+++++ & + & $+(36)$ & 1 \\
+++++ & - & & 1 \\
\hline
\end{tabular}

Maternal and foetal serology by semi-quantitative ELISA ( - to +++++$)$; $P C R$ results were qualitative $(-$ or +$)$. 
plicki and Thiry, 1998). However, a significant increase in the proportion of BoHV-4 seropositive animals in the population of cows having abortion was detected, from the fourth quarter of 2008 until the last quarter of 2009. The introduction and circulation of a new strain of BoHV-4 could be a hypothesis explaining this observation. Verna et al. (2012) showed the existence of a high variability among the BoHV-4 strains isolated from vaginal discharges of aborted cows. Unfortunately, no sample was conserved to test this hypothesis in this current study.

In our study, a relatively high seroconversion was observed at the time of abortion (primary infection or reactivation). However, this production of antibodies could have been induced by a post-partum metritis caused by the BoHV-4.

The seroconversion percentage in beef cows was significantly higher compared to dairy cows. However, no significant difference between types of breed was observed at the first sampling alone (at abortion). These data suggest that viral exposure was identical for both breeds, with viral reactivation being more frequent in beef cows. Perhaps a more intense stress in beef cows could be at the origin of the more frequent viral reactivation. Unfortunately, no additional conclusions about the breed could be brought after the second study because of the too low number of infected foetuses.

The purpose of the second study was to determine the ability of the virus to infect the foetus. The number of BoHV-4 infected foetuses (positive foetus by PCR or ELISA) was low, but non-negligible in comparison with others causes of abortions identified within the same population (Table 5). In the literature, the presence of BoHV-4 in aborted foetuses has already been investigated. Indeed, this virus has been isolated from aborted foetuses (Reed et al., 1979; Kirkbride, 1992; Wellemans and Van Opdenbosch, 1989). In Hungary, Deim and collaborators demonstrated the presence of BoHV-4 DNA in $18.18 \%$ of placentas from aborted cows in 2006 and in the spleen of $29 \%$ foetuses in 2007. In the department of Manche (France), which is geographically close to our study area, the apparent prevalence of BoHV-4 was $6.9 \%$ in 2009 (Leboeuf, 2013). The same study was completed in 2012, with 1102 samples, and BoHV-4 was found by PCR in $6.6 \%$ aborted cows (Treilles et al., 2013), which was significantly higher than what observed in our study at the same period.

The real-time PCR technique used for the direct diagnosis allows quantifying the viral DNA present in the sample. In the four PCR-positive samples, an inverse relationship between the $\mathrm{Ct}$ value and the importance of the serological reaction of the cow was observed (Table 7 ). Indeed, the foetus with the lowest $\mathrm{Ct}$ value (corresponding to the highest viral DNA detection) came from a weakly seropositive dam, while the foetus with the highest Ct came from a strongly seropositive dam. These observations could suggest an occurrence of a more recent infection in foetuses having the highest DNA detection and contemporarily in dams having the lowest seropositivity. Unfortunately, the presence of a small number of observations does not allow any further conclusions, but brings interesting data for a future study. Foetal serological diagnosis was already performed by Naeem et al. (1989), who identified specific BoHV-4 antibodies in thoracic fluids of $1.2 \%$ aborted foetuses. Transplacental transmission of BoHV-4 occurs without causing systematic foetal death (Egyed et al., 2011). In our study, despite the dams being all seropositive, foetal seroprevalence was only $0.8 \%$, without viral DNA detection by PCR in the spleen of the foetuses. These results seem to confirm the transplacental passage of BoHV-4, causing an immune response of the foetus.

Detection of BoHV-4 DNA or antibodies in aborted foetuses does not prove with certainty the role of the virus in the aetiological diagnosis of abortion, but may simply result from his presence in time of sampling or from his anterior passage. Direct diagnosis of BoHV-4 should be interpreted with great caution but is still of prime importance for diagnosis at herd level.

BoHV-4 massive infection of blood mononuclear cells could lead to a deterioration of the immune response opening the way for a multitude of clinical expressions (Thiry, 2007). As an example, immunodepression could promote the emergence of opportunistic pathogens with BoHV-4 acting as a determining factor allowing other opportunistic pathogens to intervene in the pathogenesis of abortion. Several bacteria (Arcanobacterium pyogenes, Escherichia coli, Streptococcus spp., Citrobacter spp.) were isolated from vaginal exudates in cows clinically or subclinically affected by metritis and showing seroconversion to BoHV-4 (Monge et al., 2006; Nak et al., 2011). The concomitant isolation of viruses and bacteria in the course of endometrial inflammation could be linked to a viral reactivation and the contamination by opportunistic bacteria (Donofrio et al., 2008; Sheldon et al., 2009). Similarly, Van Opdenbosch and collaborators proposed that the BoHV-4 induced immunosuppression could enhance the proliferation of opportunistic bacteria (Van Opdenbosch et al., 1984). In addition, during the second study, one or several pathogens were isolated with bacteriological analyses on the abomasal fluid from 4 of the 7 infected foetuses. Our results are in favour of the hypothesis that in the course of metritis a concomitant participation of viral and bacterial pathogens could occur (Monge et al., 2006; Nak et al., 2011).

The high level of BoHV-4 seroprevalence found in cattle confirmed the enzootic situation in the southern part 
of Belgium, as well as the frequent viral circulation among the cattle population having abortion. The seropositivity found in bovine during both studies was higher than those observed in the same area during previous studies (Van Malderen et al., 1987; Czaplicki and Thiry, 1998).

\section{Conclusions}

Despite the fact that the role of BoHV-4 as aetiological agent of a specific entity remains a matter of controversy, these two studies showed a high seroconversion for this pathogen in bovine at abortion, the proof of a foetal immunity response and the direct diagnosis of this virus in foetal spleen. These results constitute additional arguments of the possible involvement of BoHV-4 in abortion in the southern part of Belgium.

\section{Acknowledgements}

We thank Magnée D. from Thermo Fisher Scientific, Animal Health team within Applied Sciences division (Lissieu, France) and Coppe P. from Bio-X Diagnostics (Rochefort, Belgium) for providing PCR and ELISA kits, respectively. We thank the Belgian National Reference Laboratory (De Leeuw I. and De Regge N.) for providing scientific support. The costs of the basic protocol corresponding to the standardized panel of analyses were supported by the Federal Agency for the Safety of the Food Chain. The authors gratefully acknowledge their veterinary colleagues from ARSIA, that is Christian Quinet (serology), Jean Bughin and Marc Saulmont (autopsy and microbiology) and Cédric Mullender (molecular biology) for their technical assistance.

\section{References}

Bailey, N. M., M. P. Cunningham, and C. B. Kimber, 1967: The indirect fluorescent antibody technique applied to dried blood, for use as a screening test in the diagnosis of human trypanosomiasis in Africa. Trans. R. Soc. Trop. Med. Hyg. 61, 696-700.

Czaplicki, G., and E. Thiry, 1998: An association exists between bovine herpesvirus-4 seropositivity and abortion in cows. Prev. Vet. Med. 33, 235-240.

Dean, A. D., J. A. Dean, A. K. Burton, and R. C. Dicker, 1990: Epi info, Version 5: A Word Processing Database and Statistical Program for Epidemiology on Micro-Computers, pp. 252254. USD Inc., Stone Mountain, Georgia.

Deim, Z., L. Szeredi, V. Tompo, and L. Egyed, 2006: Detection of bovine herpesvirus 4 in aborted bovine placentas. Microbial. Path. 41, 144-148.
Deim, Z., L. Szeredi, and L. Egyed, 2007: Detection of bovine herpesvirus 4 DNA in aborted bovine foetuses. Can. J. Vet. Res. 71, 226-229.

Donofrio, G., L. Ravanetti, S. Cavirani, S. Herath, A. Capocefalo, and I. M. Sheldon, 2008: Bacterial infection of endometrial stromal cells influences bovine herpesvirus 4 immediate early gene activation: a new insight into bacterial and viral interaction for uterine disease. Reproduction 136, 361-366.

Edwards, S., and R. H. Newman, 1985: Detection of antibodies to bovid herpesvirus 4 by ELISA. Vet. Microbiol. 10, 149154.

Egyed, L., G. Sassi, J. Tibold, I. Madi, and O. Szenci, 2011: Symptomless intrauterine transmission of bovine herpesvirus 4 to bovine foetuses. Microb. Pathog. 50, 322-325.

Fitton, J., J. Beenham, and S. Edwards, 1990: Bovid herpesvirus4 antibody in cattle in Great Britain. Vet. Rec. 126, 173.

Kendrick, J. W., B. I. Osburn, and N. Kronlund, 1976: Pathogenicity studies on a bovine herpesvirus. Theriogenology 6, 447-462.

Kirkbride, C. A., 1992: Viral agents and associated lesions detected in a 10-year study of bovine abortions and stillbirths. J. Vet. Diagn. Invest. 4, 374-379.

Leboeuf, C., 2013: Six pour-cent d'avortements positifs en PCR pour le BHV4 dans la manche. Point Vét. 332, 60-64.

Monge, A., L. Elvira, J. V. Gonzalez, S. Astiz, and G. J. Wellenberg, 2006: Bovine herpesvirus 4-associated postpartum metritis in a Spanish dairy herd. Res. Vet. Sci. 80, 120-125.

Naeem, K., S. M. Goyal, and R. E. Werdin, 1989: Prevalence of bovid herpesvirus-4 and its antibody in cattle in Minnesota. Am. J. Vet. Res. 50, 1931-1935.

Nak, Y., S. B. Dagalp, C. Cetin, D. Nak, F. Alkan, and E. Borum, 2011: Course and severity of postpartum metritis cases following antibiotic and PGF2 $\alpha$ administration in postpartum metritis cows infected with BoHV-4. Transbound Emerg. Dis. $58,31-36$.

Petrie, A., and P. Watson, 2006: Additional Techniques in Statistics for Veterinary and Animal Science, 2nd edn. vol 14. pp. 191-211. Blackwell Science, Oxford.

Preux, P. M., P. Odermatt, A. Perna, B. Marin, and A. Vergnenègre, 2005: Qu'est-ce qu'une régression logistique ? Rev. Mal. Respir. 22, 159-162.

Reed, D. E., T. J. Langpap, and M. E. Bergeland, 1979: Bovine abortion associated with mixed Movar 33/63 type herpesvirus and bovine viral diarrhoea virus infection. Cornell. Vet. 69, $54-66$.

Sheldon, I. M., J. Cronin, L. Goetze, G. Donofrio, and H. J. Schuberth, 2009: Defining postpartum uterine disease and the mechanisms of infection and immunity in the female reproductive tract in cattle. Biol. Reprod. 81, 1025-1032.

StataCorp, 2012: Stata Statistical Software: Stata/SE Acad. 12. College Station, TX. 333 StataCorp LP.

Thiry, E., 2007: Maladies Virales Des Ruminants. 2nd edn. Éditions du Point Vétérinaire, Rueil-Malmaison 301 p. 
Treilles, M., F. Benoit, V. Carpinshi, M. Leborgne, and B. Blanchard, 2013: Progrès dans la mise en évidence du BoHV-4 en routine. Le Point Vétérinaire. 332, 66-68.

Van Malderen, G., E. Van Opdenbosch, and G. Wellemans, 1987: Bovien herpes virus 1 en 4: een sero-epidemiologisch onderzoek van de Belgische Rundveestapel. Vlaams Diergeneesk. Tijdschr. 56, 364-371.

Van Opdenbosch, E., G. Wellemans, H. Antoine, A. Broers, and G. Charlier, 1984: Chronic metritis, associated with various symptoms: an immunodepressive herpes virus (LVR 140) as etiological agent?. Vlaams Diergeneesk. Tijdschr. 53, 21-30.

Van Opdenbosch, E., G. Wellemans, H. Theys, and I. Verhees, 1986: Occurence of subclinical virus infection in veal calves and their influence on weight gain. Vlaams Diergeneesk. Tijdschr. 50, 17-20.

Verna, A. E., J. M. Manrique, S. E. Perez, M. R. Leunda, S. B. Pereyra, L. R. Jones, and A. C. Odeon, 2012: Genomic analysis of bovine herpesvirus type 4 from Argentina: High genetic variability and novel phylogenic groups. Vet. Microbiol. 160, 1-8.

Wellemans, G., 1984: Symptomatologie variée apparaîssant lors des métrites chroniques associées à un virus herpès chez les bovins. Ann. Méd. Vét. 128, 614-615.
Wellemans, G., and E. Van Opdenbosch, 1987: Transmission horizontale du virus BHV-4 à des génisses. Ann. Méd. Vét. 121, 487-491.

Wellemans, G., and E. Van Opdenbosch, 1989: Association entre l'infection par le BoHV4 et l'avortement chez la vache. Ann. Méd. Vét. 133, 347-350.

Wellemans, G., E. Van Opdenbosch, and M. Mammerickx, 1986: Experimental inoculation of bovine herpesvirus 4 (strain LVR 140) in pregnant and nonpregnant cows. Ann. Rech. Vet. 17, 89-94.

Wellenberg, G. J., E. M. A. Van Rooij, J. Maissan, and J. T. Van Oirschot, 1999: Evaluation of newly developed immunoperoxidase monolayer assays for detection of antibodies against bovine herpesvirus 4. Clin. Diagn. Lab. Immunol. 6, 447-451. Wellenberg, G. J., E. R. A. M. Verstraten, S. Belak, S. B. E. Verschuren, F. A. M. Rijsewijk, R. Peshev, and J. T. Van Oirschot, 2001: Detection of bovine herpesvirus 4 glycoprotein B and thymidine kinase DNA by PCR assays in bovine milk. J. Virol. Methods 97, 101-112. 